\title{
The Effects of the Application of Generative Learning Model with Brainstorming Technique on Students' Mathematical Reasoning and Communication Abilities
}

\author{
Virdian Dwi Cahyaningrum \\ Department of Mathematics Education \\ University of Muhammadiyah Malang \\ Malang, Indonesia
}

\author{
Mohammad Syaifuddin *) \\ Department of Mathematics Education \\ University of Muhammadiyah Malang \\ Malang, Indonesia \\ ${ }^{*}$ corresponding author's email: \\ syaifuddin@umm.ac.id
}

\author{
Moh. Mahfud Effendi \\ Department of Mathematics Education \\ University of Muhammadiyah Malang \\ Malang, Indonesia
}

\begin{abstract}
The purpose of the research was to analyze the effect of the application of generative learning model with brainstorming technique on students' mathematical reasoning and communication abilities in State Junior High. The sample of the research included the students of Grade VIIIa in total of 16 students of State Junior High School 2, Karangrejo, Tulungagung. A quantitative approach with one group pretestposttest experimental design was adopted. The class was taken randomly. The data were collected using tests and interviews. The data were analyzed using a paired sample $t$ - test with the significance level of 0.05 . The research result has revealed that the generative learning model with brainstorming technique contributed significant effects on the students' mathematical reasoning and communication abilities.
\end{abstract}

Keywords: Generative learning model, brainstorming technique, reasoning abilities, mathematical communication abilities

\section{INTRODUCTION}

Mathematics is the mother of other sciences, and thus the learning provided to students should not merely focus on students' memorizing existing formulas [1] [1]. Moreover, etymologically, mathematics is a science obtained using reasoning [2]. In order to reach learning objectives, teachers have great tasks and responsibilities as facilitators, encouragers, and also mentors for their students during any learning process [3]. According to Supriadi \& Darmawan (2012), a professional teacher is the one who is able to plan and implement learning activities in a pleasing, dialogic, democratic, cooperative, and meaningful atmosphere. Moreover, a teacher is also to develop students' thinking skills, from simple to more complex ones. In order to reach such condition, teachers should adopt a proper learning method, model, strategy, and technique.

The results of observations and interviews showed that the teaching-learning activities in State Junior High School 2 Karangrejo Tulungagung were implementing conventional methods. The teachers were still more active in the learning process. Although the students discussed in groups to solve mathematical problems, their reasoning and communication abilities were still considered low.

Learning activity with the base of constructivism view may be implemented with various types of learning model; one of which is generative learning model. This generative learning model is a learning model that makes students' brain not to be passive in receiving information. Students' brain will be more actively be trained to construct an interpretation of the information and to make conclusions [5], [6]. The implementation of generative method in mathematics learning may improve students' learning abilities [5]. According to Shohimin (2014), the implementation of generative learning model consists of 5 stages namely orientation, expression of ideas, challenges and restructuring, applying the concept, and reviewing.

Each learning model certainly has some weaknesses. The weakness existing in the generative learning model is that during the discussion, students are still able to criticize their fellow students [6]. This happens because in this learning model, no rule exists in the discussion activity. To reduce criticism during the discussion activity, in the generative learning model, a brainstorming technique is adopted. Brainstorming technique is a discussion technique applied in groups to collect ideas, opinions, information, knowledge, or experiences from all students as alternative answers to problems they meet which they use to solve the problems [3], [8]. In implementing the brainstorming technique, a rule is prevailed namely students are not allowed to criticize any opinions given by other students. The implementation of brainstorming technique could improve students' mathematical communication in Junior High School [9]. Moreover, Alrubaie \& Daniel (2014) state that in the process of problem solving with brainstorming technique, students showed analysis, reasoning, and critical thinking through their left brain. According to Tina et al. (2013), the syntax of brainstorming 
technique is as follows: posing problems, giving information and rules in the discussion, as well as expressing ideas and verification.

The generative learning model collaborated with the brainstorming technique is to help students solve problems and sharpen their mathematical reasoning and communication abilities and actively integrate their new knowledge with the previous one so that their brain would not passively obtain information [11]. When students make conclusions based on their previous knowledge and their new one, they use their reasoning abilities. After they make their conclusions, they communicate their findings to other students with global mathematical language that may help them solve mathematical problems. Moreover, to facilitate students during the discussion, and to enable all students to express their ideas without being afraid of criticism from other students, a brainstorming technique is employed. Brainstorming technique is one of the ways to solve problems by accommodating all ideas presented [3]. The application of the combination between generative learning model and brainstorming technique is expected to improve students' reasoning and mathematical communication abilities. The learning stages of the combination between generative learning model and brainstorming technique are as follows: orientation, posing a problem, information and rules in the discussion, expressing ideas, challenges and restructuring, verification, application, and reviewing [7], [8].

The goals of learning mathematics according to NCTM among others are mathematical reasoning and communication abilities. Mathematical reasoning is an ability to make a conclusion based on relevant sources and some valid statements [12], [13]. The indicators of reasoning abilities in this research are as follows: students are able to estimate solutions and solution processes, to make mathematical manipulations, to examine the validity of an argument, to arrange and give evidence to the correctness of any solutions, as well as to make analogy and generalization [14], [15]. Mathematical communication ability represents a skill to organize thoughts, apply and express the understanding of mathematical concepts either in oral or written form [16], [17]. The indicators of written communication abilities are as follows: students are able to state a situation or idea in the form of models, pictures, graphs, tables/diagrams, and explain an idea or situation of pictures, diagrams, tables or graphs with their own words in their writing. While the indicators of oral mathematical communication are that students are able to explain their mathematical ideas to other people orally [17], [18]. In this current research, the ability of written mathematical communication was investigated.

Principally, it can be stated that the generative learning model collaborated with the brainstorming technique may help students sharpen their mathematical reasoning and communication abilities. This model also has shown that students become more active; their learning are more meaningful and pleasing. From the descriptions above, the objective of this present research was to analyze the effects of the application of the generative learning model with brainstorming technique on students' mathematical reasoning and communication abilities.

\section{RESEARCH METHOD}

A quantitative approach was employed in this present research. Quantitative approach is intended to analyze data in numerical forms using statistics. The type of this research was quasi-experimental with one group pretest-posttest design where the grade was chosen randomly [19], as follow:

Table 1. Research Design

\begin{tabular}{|c|c|c|}
\hline Pretest & Treatment & Posttest \\
\hline$O_{1}$ & $X_{1}$ & $O_{2}$ \\
\hline
\end{tabular}

Note:

$X_{1}$ : the generative learning with brainstorming technique

$O_{1}:$ pretest

$\mathrm{O}_{2}$ : posttest

The population in this research included students in Grade 8, even semester, in State Junior High School 2 Karangrejo in the academic year of 2016/2017, consisting of 4 classes, where each class contained 21 students. The total number of the students is 84 . The research samples were chosen randomly from the population, in total of 21 students in Grade 8 to get the treatment, namely the application of the generative learning model with brainstorming technique. However, the number of the students who took the test was 16 students.

The techniques of data collection were tests and interviews. The tests were used to tap students' mathematical reasoning and communication abilities before and after the generative learning model with brainstorming techniques was applied. An essay test was given to the students individually, administrated at the beginning and at the end of the research. Interviews were conducted to cross check the results of the students' written tests. The data obtained were analyzed using Kolmogorov-Smirnov's normality test and the hypothesis was tested using a paired sample t-test by using significance level of 0.05 .

\section{RESULTS AND DISCUSSION}

Kolmogorov-Smirnov's normality test is one of the procedure that can be used to test of data normality. The results of the normality test using the Kolmogorov-Smirnov's test with IBM SPSS 21 program are shown in Table 2.

Table 2. Kolmogorov-Smirnov Test

\begin{tabular}{|c|c|c|c|c|}
\hline Abilities & Data & $\begin{array}{c}p- \\
\text { value }\end{array}$ & $\alpha$ & $\begin{array}{c}\text { Data } \\
\text { Distribution }\end{array}$ \\
\hline \multirow{2}{*}{ Reasoning } & Pretest & 0.200 & 0.05 & Normal \\
\cline { 2 - 5 } & Posttest & 0.167 & 0.05 & Normal \\
\hline \multirow{2}{*}{ Communication } & Pretest & 0.87 & 0.05 & Normal \\
\cline { 2 - 5 } & Posttest & 0.200 & 0.05 & Normal \\
\hline
\end{tabular}


Table 2 showed that the data of reasoning and communication abilities were normally distributed. After the normality test is proven, the further analysis was the paired sample t-test conducted using the IBM SPSS 21 program. By using the level of significance of 0.05 , the results of this analysis are as below.

Table 3. Paired Sample t-test, $N=16$

\begin{tabular}{|c|c|c|c|c|c|c|c|}
\hline Abilities & Data & Mean & SD. & $\begin{array}{c}\text { SE } \\
\text { Mean }\end{array}$ & $\mathrm{t}$ & $r$ & $\begin{array}{c}\mathrm{p}- \\
\text { value }\end{array}$ \\
\hline \multirow{2}{*}{ Reasoning } & Pretest & 10.44 & \multirow{2}{*}{3.16} & \multirow{2}{*}{0.79} & \multirow{2}{*}{$\begin{array}{c}- \\
2.14\end{array}$} & \multirow{2}{*}{0.807} & \multirow{2}{*}{0.049} \\
\hline & Posttest & 12.13 & & & & & \\
\hline \multirow{2}{*}{ Communication } & Pretest & 10.88 & \multirow{2}{*}{1.98} & \multirow{2}{*}{0.50} & \multirow{2}{*}{$\begin{array}{c}- \\
3.53\end{array}$} & \multirow{2}{*}{0.874} & \multirow{2}{*}{0.003} \\
\hline & Posttest & 12.63 & & & & & \\
\hline
\end{tabular}

On Table 3, the results of the calculation using the paired sample t-test of the students' reasoning abilities showed that the $p$-value was 0.049 , lower than 0.05 . It can be concluded that the application of the generative learning model with brainstorming technique has affected on the students' reasoning abilities. The mean difference between the students' reasoning abilities before and after the treatment was 1.68. The Correlation coefficient $(r)$ of the students' learning abilities was 0.807 , then $r^{2}=(0.807)^{2}$ was 0.65 . It means that the improvement of the students' reasoning abilities caused by the application of the generative learning model with brainstorming technique was $65 \%$ and the rest was caused by other factors.

Dealing with the students' mathematical communication abilities, the results of the calculation have shown that the $\mathrm{p}$ value was 0.003 , smaller than 0.05 . It can be concluded that the application of the generative learning model with brainstorming technique has affected on the students' mathematical communication abilities. The mean difference between the students' mathematical communication abilities before and after the treatment was 1.75 . The Correlation coefficient $(r)$ of the students' mathematical communication abilities was 0.874 , then $r^{2}=(0.874)^{2}$ was 0.76. It means that the improvement of the students' mathematical communication abilities was caused by the application of the generative learning model with brainstorming technique accounted for $76 \%$ and the rest was caused by other factors.

The results of the data analysis on the basis of the results of the students' pretest and posttest have shown that $65 \%$ of the students' reasoning improvement has been influenced by the application of the generative learning model with brainstorming technique; where $76 \%$ improvement of the students' mathematical communication skill has been influenced by the application of the generative learning model with brainstorming technique. It is in line with the previous researches that the generative learning model is able to improve students' mathematical reasoning ability [5] and communication ability [9], [20]. In addition, the cognitive processes associated with the brainstorming technique include creative and critical thinking, as well as problem solving skills [10].

\section{CONCLUSION}

Departing from the results and discussion of this current research, it has been shown that there were significant effects of the generative learning model with brainstorming technique on the students' mathematical reasoning and communication abilities in State Junior High School 2 Karangrejo Tulungagung. The improvement of the students' reasoning and communication abilities have been contributed by the implementation of the generative learning model with brainstorming technique accounted for $65 \%$ and $76 \%$ respectively, and the rests have been influenced by other factors.

\section{REFERENCES}

[1] W. Sugiarto, "Penerapan Pembelajaran Berbasis Masalah Berbantuan Geogebra Untuk Meningkatkan Motivasi dan prestasi Belajar Materi Komposisi Transformasi," J. Math. Educ. IKIP Veteran Semarang, vol. 1, no. 1, pp. 42-48, 2017.

[2] A. Amir, "Kemampuan Penalaran dan Komunikasi dalam Pembelajaran Matematika," Logaritma, vol. II, no. 1, pp. 18-33, 2014.

[3] Slameto, Belajar dan Faktor-faktor yang Mempengaruhi. Jakarta: PT. Rineka Cipta, 2013.

[4] D. Supriadi and D. Darmawan, Komunikasi Pembelajaran. Bandung: PT Remaja Rosdakarya, 2012.

[5] I. Zulkarnain and A. Rahmawati, "Model Pembelajaran Generatif untuk Mengembangkan Kemampuan Penalaran Matematis Siswa," $J$. Pendidik. Mat., vol. 2, no. 1, pp. 8-14, 2014.

[6] S. Mawaddah and H. Anisah, "Kemampuan Pemecahan Masalah Matematis Siswa Pada Pembelajaran Matematika Dengan Menggunakan Model Pembelajaran Generatif (Generative Learning) Di SMP," EDU-MAT J. Pendidik. Mat., vol. 3, no. 2, pp. $166-175,2015$.

[7] A. Shohimin, 68 Model Pembelajaran Inovatif dalam Kurikulum 2013. Yogyakarta: Ar-Ruzz Media, 2014.

[8] R. Tina, E. Gani, and Nursaid, "Peningkatan Pembelajaran Menuis Argumentasi Melalui Model Pembelajaran Brainstorming," J. Pendidik. Bhs. dan Sastra Indones., vol. 1, no. 2, pp. 57-63, 2013.

[9] M. S. R. Siti, "Pendekatan Brainstorming RoundRobin Untuk Meningkatkan Kemampuan Komunikasi Matematis Siswa SMP," J. Ilm. Progr. Stud. Mat. STKIP Siliwangi Bandung, vol. 4, no. 2, pp. 190-196, 2015.

[10] F. Alrubaie and E. G. S. Daniel, "Revisiting the Cognitive Processes of the Brainstorming Technique: Theoretical Considerations from a Synthesis of Piaget , Vygotsky and SIAM for Learning Science," Int. J. Thesis Proj. Diss., vol. 2, no. 3, pp. 44-57, 2014.

[11] D. Hamdani, E. Kurniati, and I. Sakti, "Pengaruh 
Model Pembelajaran Generatif dengan Menggunakan Alat Peraga Terhadap Pemahaman Konsep Cahaya Kelas VIII di SMP Negeri 7 Kota Bengkulu," J. Exacta, vol. 10(1), 2012.

[12] Y. Aditya, E. Mulyana, and C. Kustiawan, "Implementasi Model Pembelajaran Matematika Knisley dalam Upaya Meningkatkan Kemampuan Penalaran Matematis Siswa SMA," J. Pengajaran MIPA, vol. 17, no. 1, pp. 8-16, 2012.

[13] I. Lestari, R. C. . Prahmana, and W. Wiyanti, "Peningkatan Kemampuan Penalaran Matematis Siswa Menggunakan Pendekatan Pendidikan Matematika Realistik," J. Inov. Pendidik. Dasar, vol. 1, no. 2, pp. 1-8, 2016.

[14] H. Sugilar, "Daya Matematis Mahasiswa Program Studi Pendidikan Matematika," J. Nas. Pendidik. Mat., vol. 1, no. 1, pp. 97-108, 2017.

[15] Sulistiawati, D. Suryadi, and S. Fatimah, "Peningkatan Kemampuan Penalaran Matematis Menggunakan Desain Didaktis Berdadasarkan Kesulitan Belajar pada Materi Luas dan Volume," Jppm, vol. 9, no. 1, pp. 175-188, 2016.

[16] H. Sugiarto and M. T. Budiarto, "Kemampuan
Komunikasi Matematika Siswa SMP dalam Pemecahan Masalah Ditinjau dari Kemampuan Matematika," J. Ilm. Pendidik. Mat., vol. 3(3), pp. 16, 2014

[17] D. Rachmayani, "Penerapan Pembelajaran Reciprocal Teaching Untuk Meningkatkan Kemampuan Komunikasi Matematis Dan Kemandirian Belajar Matematika Siswa," J. Pendidik. Unsika, vol. 2, no. November, pp. 13-23, 2014.

[18] H. P. I. Wijaya, I. Sujadi, and Riyadi, "Kemampuan Komunikasi Matematis Siswa Sesuai dengan Gender dalam Pemecahan Masalah pada Materi Balok dan Kubus (Studi Kasus pada Siswa Kelas VIII SMP Islam Al-Azhar 29 Semarang)," J. Elektron. Pembelajaran Mat., vol. 4, no. 9, pp. 778-788, 2016.

[19] Sugiyono, Metode Pedelitian Pendidikan. Bandung: Alfabeta, 2015.

[20] Isnaeni and R. Maya, "Meningkatkan Kemampuan Komunikasi dan Disposisi Matematik Siswa Sekolah Menengah Atas Melalui Pembelajaran Generatif," J. Pengajaran MIPA, vol. 19, no. 2, pp. 159-165, 2014. 